\title{
Article Quality Attributes of Malaysia Purple-Fleshed Sweet Potato at
Different Peel Condition
}

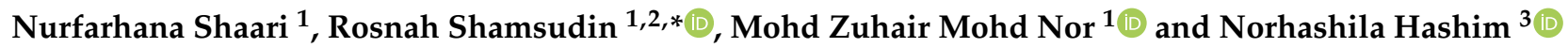 \\ 1 Department of Process and Food Engineering, Faculty of Engineering, Universiti Putra Malaysia, \\ Serdang 43400, Selangor, Malaysia; nurfashaari2008@gmail.com (N.S.); zuhair@upm.edu.my (M.Z.M.N.) \\ 2 Institute of Advanced Technology, Universiti Putra Malaysia, Serdang 43400, Selangor, Malaysia \\ 3 Department of Biological and Agricultural Engineering, Faculty of Engineering, Universiti Putra Malaysia, \\ Serdang 43400, Selangor, Malaysia; norhashila@upm.edu.my \\ * Correspondence: rosnahs@upm.edu.my; Tel.: +60-3-9769-6366
}

Citation: Shaari, N.; Shamsudin, R.; Nor, M.Z.M.; Hashim, N. Quality Attributes of Malaysia Purple-

Fleshed Sweet Potato at Different Peel Condition. Agronomy 2021, 11, 872. https://doi.org/10.3390/ agronomy 11050872

Academic Editors: Richard G. F. Visser and Carlos Iglesias

Received: 24 February 2021

Accepted: 22 April 2021

Published: 29 April 2021

Publisher's Note: MDPI stays neutral with regard to jurisdictional claims in published maps and institutional affiliations.

Copyright: () 2021 by the authors. Licensee MDPI, Basel, Switzerland. This article is an open access article distributed under the terms and conditions of the Creative Commons Attribution (CC BY) license (https:// creativecommons.org/licenses/by/ $4.0 /)$.

\begin{abstract}
In this study, physical and chemical properties (dry matter, ash, moisture, protein, fat, fiber, carbohydrate, starch, amylose, and vitamin C) of sweet potato tuber and flour of Anggun 1 cultivar were evaluated at different conditions. During peeling, the tuber and flour were processed subjected to three different conditions, which were unpeeled tubers (C1), peeled tubers (C2), and skin of tuber only (C3). From the results, the highest $(p<0.05)$ dry matter was observed in $\mathrm{C} 1$ while higher contents of ash, moisture, and protein were found in C3. Regarding the fat and vitamin $\mathrm{C}$ content, no significant differences $(p>0.05)$ were found between each condition. The highest fiber, carbohydrate, and amylose content $(p<0.05)$ were found in $\mathrm{C} 1$. The $\mathrm{C} 1$ and $\mathrm{C} 2$ reflected significantly higher $(p<0.05)$ starch content. Overall, these results provide important information about the peeling effect on the physical and chemical properties of Anggun 1. The information could be used as adding value to healthy food in the Malaysian diet due to the nutritional value of sweet potato.
\end{abstract}

Keywords: sweet potato; quality; peeled; unpeeled; skin

\section{Introduction}

Sweet potato tubers (Ipomoea batatas) belong to the family of Morning glories and genus Ipomoea. The high demand for sweet potatoes due to excellent sources of carbohydrates and economic production has contributed to the growing plantation area of sweet potatoes all over the world. In Malaysia, sweet potato production increased from about 26,582 in 2011 to 41,245 in 2017, with the states of Perak, Kelantan, and Terengganu being the main representative areas [1]. Jalomas, Gendut, VitAto, and Anggun are the famous varieties developed by the Malaysian Agriculture and Development Institute (MARDI). In 2017, MARDI had released three types of Anggun viz. Anggun 1, Anggun 2, and Anggun 3. These varieties have purple skin and flesh. They are different from each other in terms of morphological characteristics. [2] In this research, Anggun 1 was selected as the sample during the study. This is because the production of Anggun 1 is quite high compared to other types of Anggun. Moreover, the long and elliptical shape of Anggun 1 is the ideal one and fulfills the market demand. It also has high anthocyanin content, capable to survive in low-fertility soil, as well as tolerant to drought and disease, which makes it one step further than other varieties of sweet potato.

Sweet potato is a common staple food that belongs to the Malaysian diet. It is appreciated for its sensorial quality and is known as an energy source in the human diet [3]. Another interesting fact concerning this tuber is that it has been reported to be an effective enhancer of the essential nutrients of foods, with tubers being among the best sources of carbohydrates. Besides carbohydrates, starch also can be found as an important element in this tuber [3,4]. Moreover, the health-promoting effects associated with the consumption of sweet potato have been attributed to the abundance of nutrient compositions, including 
protein, dietary fiber, and vitamin C [4,5]. Therefore, the increased production of this tuber has been associated not only with high consumer acceptance due to its sensory attributes but also with the presence of beneficial biochemical composition for consumer health, such as anti-inflammatory and anti-oxidative compounds [6].

Sweet potato can be processed into various products such as cookies, biscuits, muffins, noodles, and pies, with longer shelf-life, and improvement in its characteristics. It can also be processed into flour, which is less bulky and high stability than the perishable fresh tuber. In the food industry, the flour can be used as a thickener in soup, gravy, fabricated snacks, and bakery products. The findings by $[7,8]$ showed that the physical and chemical properties of sweet potato flour were mainly determined by starch and other components such as dry matter, ash, moisture, protein, fat, fiber, carbohydrate, amylose, and vitamin C. As mentioned by [7], an ideal flour should have a high starch, low fiber, and low ash content. In product development, the raw ingredients used will affect the final quality of the product [9]. Hence, a high-quality sweet potato is required to obtain a high-quality derived product.

Processing technology of tuber into flour involved several steps including a selection of raw material, cleaning and trimming, washing and brushing, slicing, drying, milling, packaging, and storage [10]. It has been noted that the skin of sweet potato has a protective effect on water diffusion from the roots towards the surface, which provides a harder structure and not easily breakable. Therefore, peeling is a new technology of flour production from outside to inside. It is a process that involves peeling off the sweet potato surface and then smashing. Compared with the common method of milling without peeling off the surface, it has the advantages of a short processing procedure and more nutrients retained. On the other hand, peeling flour has better processing characteristics than the production of unpeeled tuber flour by direct grinding [11,12].

In the present study, different conditions (unpeeled tubers, peeled tubers, and skin) of Anggun 1 sweet potato cultivar produced in Malaysia were assessed in terms of nutritional composition through analysis of physical and chemical attributes such as dry matter, ash, moisture, protein, fat, fiber, carbohydrate, starch, amylose, and vitamin C. Therefore, this study aimed to study the effect of different conditions (unpeeled tubers, peeled tubers, and skin) of Anggun 1 sweet potato cultivar produced in Malaysia on the nutritional composition of sweet potato tuber and flour.

\section{Materials and Methods}

\subsection{Raw Materials}

The sample preparation was adapted from [13]. Sweet potato cultivar (Ipomoea batatas Lam cv. Anggun 1) was obtained from the commercial sweet potato farm in the western West of Malaysia (Selangor). The sweet potato harvest time was carried out by farmers at 3 to 4 months after plantation according to the maturation stage. Three hundred and fifty tubers $(\sim 20 \mathrm{~kg})$ were picked and transported to the laboratory. Tubers were washed with tap water to remove dirt and soil. After drying its surface, the cleaned tubers were stored at $4{ }^{\circ} \mathrm{C}$ until further analysis.

\subsection{Sample Preparation of Sweet Potato Tubers}

Sweet potato tubers were divided into three groups. In the first group (C1), unpeeled sweet potatoes were cut into slices of $5 \mathrm{~mm}$ thickness using a sharp stainless steel knife (86902, John Craft, Malaysia). For the second group (C2), sweet potatoes were peeled with a hand peeler (Peeler Stainless Steel 22, Barbarian, Thailand). For the third group (C3), the skins of sweet potatoes were peeled about $1 \mathrm{~mm}$ thickness from the tuber. All samples were placed in auto seal bags and kept in a desiccator to inhibit moisture gain or loss. They were then ready for the determination of physical and chemical properties. 


\subsection{Sample Preparation of Sweet Potato Flour}

Sweet potato tubers were divided into three groups as in Section 2.2. Then, all samples were oven-dried at $60^{\circ} \mathrm{C}$ for $7-8 \mathrm{~h}$ using a oven (DO6836, Memmert GmbH, Schwabach, Germany) until the moisture content of the samples was 6-7\% [9]. The hot-air drying method was used because it is the most common method of drying agricultural crops. Furthermore, it is a nontoxic and naturally harmless method and provides a more uniform dried product [14]. The flour was obtained by grinding the dried slices of sweet potato tubers using a laboratory-scale grinder (HR-20B-AEC, AEC Machinery, Malaysia) and sieved through a $300 \mu \mathrm{m}$ sieve (AS200, Retsch, Dusseldorf, Germany). The flour samples were packaged in plastic bags, sealed, and stored in a chiller (LF817LD, ASEC0 ${ }^{\circledR}$, Shah Alam, Malaysia) at $4{ }^{\circ} \mathrm{C}$ for physical and chemical analysis.

\subsection{Determination of the Physical and Chemical Properties}

\subsubsection{Dry Matter Content (DM)}

Dry matter (DM) content refers to the material in the food sample after the removal of water. DM content of sweet potato was determined according to the method [15]. About $5 \mathrm{~g}$ of sweet potato tuber and flour samples $(\mathrm{C} 1, \mathrm{C} 2$, and $\mathrm{C} 3)$ were weighed and dried in the oven (UNB 400, Memmert, Schwabach, Germany) at $80^{\circ} \mathrm{C}$ for $24 \mathrm{~h}$. The percentage of DM content for the samples was determined according to Equation (1) [15]:

$$
\text { Dry matter content }(\%)=\frac{\text { Dry weight of sample }}{\text { Total weight of sample }} \times 100
$$

\subsubsection{Ash Content}

Ash content is an inorganic residue that remained in the food sample after the removal of water and organic matter. Ash content was determined according to the AOAC method [16] based on the vaporization of water and volatiles by burning organic substances in the presence of oxygen in the air to carbon dioxide (dry ashing). About $1 \mathrm{~g}$ of tuber and flour samples (C1, C2, and C3) were weighed and placed in a porcelain crucible and incinerated at $525^{\circ} \mathrm{C}$ for $2-4 \mathrm{~h}$ in an ashing muffle furnace (KSL-1700X, MTI Corporation; Richmond, USA) until the residues were completely turned white. The percentage of ash content was calculated and expressed on a dry basis as the following Equation (2):

$$
\text { Ash content, dry basis }(\%)=\frac{\text { Weight of ash }}{\text { Initial weight of sample }} \times 100
$$

\subsubsection{Moisture Content (MC)}

Moisture content is generally reflected in the amount of water present in the food. It is essential to know the moisture content as it affects the weight of the food. The moisture content of sweet potato tuber and flour samples (C1, C2, and C3) was determined according to the AOAC method [17] via a thermogravimetric approach by loss on drying. Each crucible was thoroughly washed and dried in an oven at $100{ }^{\circ} \mathrm{C}$ for $30 \mathrm{~min}$ and allowed to cool inside a desiccator. The cooled crucible was weighed using weighing balance and recorded as W1. Then, $2 \mathrm{~g}$ of sample (C1, C2, and C3) was put into the crucible and weighed to determine $\mathrm{W} 2$. Thereafter, the sample with crucible was placed and dried in an oven (UNB 400, Memmert, Schwabach, Germany) at $105^{\circ} \mathrm{C}$ for $4 \mathrm{~h}$, then cooled and weighed at the same temperature for 30 min until a constant weight was obtained and weight was recorded as W3. Then, the moisture content of the sample was calculated from Equation (3):

$$
\text { Moisture content, dry basis }(\%)=\frac{\mathrm{W} 2-\mathrm{W} 3}{\mathrm{~W} 2-\mathrm{W} 1} \times 100
$$

where; W1: Initial weight of empty crucible (g); W2: Initial weight of filled crucible (g); W3: Final weight of filled crucible (g). 


\subsubsection{Crude Protein}

The protein content was determined using the Kjeldahl method according to the AOAC method [17]. For protein digestion, $2 \mathrm{~g}$ of sweet potato tuber and flour samples (C1, $\mathrm{C} 2$, and C3) were weighed and 2 tablets of Kjedahl catalyst were added into a Kjeldahl flask. Subsequently, $25 \mathrm{~mL}$ of concentrated sulphuric acid $\left(\mathrm{H}_{2} \mathrm{SO}_{4}\right)$ was poured into the Kjeldahl flask. The digestion was carried out at a temperature above $420^{\circ} \mathrm{C}$ for $1 \mathrm{~h}$. After $1 \mathrm{~h}$, the samples were allowed to cool. Next, the distillation process was carried out with $5 \mathrm{~mL}$ of boric acid was added into the Kjeldahl flask. Then, $5 \mathrm{~mL}$ of the digest was pipetted into the Kjeltec distillation apparatus (KjeltecTM 2300, Foss Analytical; Hilleroed, Denmark). After the digest was washed with distilled water, $50 \mathrm{~mL}$ of $60 \% \mathrm{NaOH}$ solution was added, and ammonium sulfate was collected sufficiently. The digest went through the steaming process for 1 to $5 \mathrm{~min}$. The percentage of crude protein for the sample was recorded automatically on the screen of the apparatus.

\subsubsection{Crude Fat}

The fat content was determined according to the Soxhlet extraction method [17] using Soxtec Extraction (SoxtecTM 2050, Foss Analytical, Hilleroed, Denmark). First, a 250 mL aluminum cup was cleaned and dried in an oven at 105 to $110^{\circ} \mathrm{C}$ for $30 \mathrm{~min}$ and cooled in a desiccator. The cooled aluminum cup was weighed and recorded as $\mathrm{W} 1$. Then, $80 \mathrm{~mL}$ of petroleum ether was poured into the cup. Approximately, $1 \mathrm{~g}$ of sweet potato tuber and flour samples (C1, C2, and C3) were weighed (W2) and put into the labeled extraction thimbles with cotton wool. The aluminum cup and extraction thimbles were attached to the Soxhlet apparatus. The Soxhlet apparatus was allowed to reflux for $75 \mathrm{~min}$. The collected petroleum ether in the aluminum cup was drained into another container and dried at $105^{\circ} \mathrm{C}$ for $1 \mathrm{~h}$. The aluminum cup was allowed to cool and weighed after that (W3). The fat percentage was calculated according to Equation (4) [17]:

$$
\text { Fat content, }(\%)=\frac{\mathrm{W} 3-\mathrm{W} 1}{\mathrm{~W} 2} \times 100
$$

where; W1: Initial weight of empty aluminum cup (g); W2: Initial weight of the sample (g); W3: Final weight of aluminum cup (g).

\subsubsection{Crude Fiber}

The crude fiber was determined according to the AOAC method [17]. The crucible was washed and dried in an oven for $1 \mathrm{~h}$ at $105^{\circ} \mathrm{C}$ and then cooled in a desiccator. The weight of the cool crucible was recorded (W1). About $1 \mathrm{~g}$ of sweet potato tuber and flour samples (C1, C2, and C3) were weighed (W2) and put into the empty crucible. Then, $1 \mathrm{~g}$ of filter agent using Celite 545 diatomaceous earth (Sigma Aldrich, Darmstadt, Germany) was added into the crucible and weighed (W3). The sample and Celite were dissolved in $200 \mathrm{~mL}$ of boiling $0.25 \mathrm{~N}$ sulphuric acid $\left(\mathrm{H}_{2} \mathrm{SO}_{4}\right)$ and boiled for $30 \mathrm{~min}$ using the fibertec machine (Fibertec $^{\mathrm{TM}}$ 2010, Foss Analytical; Hilleroed, Denmark). The mixture filtered through the crucible and rinsed with boiled water. Next, $200 \mathrm{~mL}$ of boiled $0.313 \mathrm{~N}$ sodium hydroxide $(\mathrm{NaOH})$ was added to the crucible and boiled for $30 \mathrm{~min}$. The hydrolyzed sample was filtered again and rinsed with boiled distilled water. The residues in the crucible were dried in an oven at $105^{\circ} \mathrm{C}$ until a constant weight was achieved. The dried samples were then placed in the muffle furnace at $550{ }^{\circ} \mathrm{C}$ until completely burned. The crucibles were then placed in a desiccator until a constant weight was achieved (W4) and the crude fiber was calculated according to Equation (5) [17]:

$$
\text { Crude fiber, }(\%)=\frac{(\mathrm{W} 3-\mathrm{W} 1)-(\mathrm{W} 4-\mathrm{W} 1)}{\mathrm{W} 2} \times 100
$$

where; W1: Initial weight of empty crucible (g); W2: Initial weight of sample (g); W3: Initial weight of crucible + sample + Celite 545 (g); W4: Final weight of crucible + sample + Celite $545(\mathrm{~g})$ after ashed. 


\subsubsection{Carbohydrate}

The phenol sulphuric acid method is an example of a colorimetric method that is widely used to estimate the total concentration of carbohydrates present in foods. The method was performed according to [18]. First, $100 \mathrm{mg}$ of the sweet potato tuber and flour samples (C1, C2, and C3) were weighed and put into boiling tubes. The samples were hydrolyzed by keeping them in a boiling water bath for $3 \mathrm{~h}$ with $5 \mathrm{~mL}$ of $2.5 \mathrm{~N}-\mathrm{HCl}$ and cooled to room temperature. Then, the mixture was neutralized with solid sodium carbonate until the effervescence ceases and made up the volume to $100 \mathrm{~mL}$. The mixture was then centrifuged. For standard preparation, $0.2,0.4,0.6,0.8$, and $1 \mathrm{~mL}$ (with $0.1 \mathrm{mg} / \mathrm{mL}$ concentration) of the working standard (glucose) were pipetted out into a series of test tubes with a blank was set with $1 \mathrm{~mL}$ of water. Next, $0.2 \mathrm{~mL}$ of the sample solution was pipetted out into another test tube. The volume in each tube of standard and sample was made up to $1 \mathrm{~mL}$ with distilled water. Each tube was added with $1 \mathrm{~mL}$ of phenol solution and $5 \mathrm{~mL}$ of $96 \%$ sulphuric acid and shook well. After $10 \mathrm{~min}$, the tubes were shaken again and placed in a water bath at $25-30{ }^{\circ} \mathrm{C}$ for $20 \mathrm{~min}$. The absorbance was read at $490 \mathrm{~nm}$. The concentration of carbohydrate $(\mathrm{mg}$ glucose $/ \mathrm{mL}$ ) of the sample was obtained as compared with the standard curve of glucose.

\subsubsection{Starch Content}

Starch determination was performed according to [19] using the Phenol-sulphuric acid method as followed. First, $50 \mathrm{~g}$ of sweet potato tuber and flour samples ( $\mathrm{C} 1, \mathrm{C} 2$, and C3) were extracted with hot $80 \%$ ethanol to separate between starch and sugar. Then, $1 \mathrm{~mL}$ of the extract was pipetted into a test tube and diluted to $2 \mathrm{~mL}$ with distilled water. The tube was added with $1 \mathrm{~mL}$ of $5 \%$ phenol and mixed thoroughly. $5.0 \mathrm{~mL}$ of concentrated sulphuric acid was added and the tube was allowed to stand for $10 \mathrm{~min}$. The mixture was vortexed and allowed to stay for another $20 \mathrm{~min}$ prior to absorbance reading at $490 \mathrm{~nm}$. A standard curve was plotted using $0-100 \mu \mathrm{g}$ glucose. A standard solution of glucose was prepared by dissolving $10 \mathrm{mg}$ of glucose in $100 \mathrm{~mL}$ distilled water. $0.20,0.40,0.60,0.80$, and $1.00 \mathrm{~mL}$ of the standard glucose solution was pipetted into a test tube and treated following the procedure for starch extract. The amount of starch in the powder sample was determined by reference to the standard curve while taking the dilution factor and weight sample into consideration. Starch was calculated using Equation (6):

$$
\text { Starch }(\%) \frac{D \times A \times 1 / M}{\text { Weight of sample }} \times 0.9 \times 100 \%
$$

where; $D$ : dilution factor; $A$ : absorbance; $M$ : slope of standard curve; 0.9 : factor to convert from free glucose to starch.

\subsubsection{Amylose Content}

Amylose content of sweet potato tuber and flour samples (C1, C2, and C3) was determined using the method as described by [20]. First, $20 \mathrm{mg}$ of sample (C1, C2, and C3) was weighed into a $50 \mathrm{~mL}$ beaker and $10 \mathrm{~mL}$ of $0.5 \mathrm{~N} \mathrm{KOH}$ solution was added. The mixture was stirred with a stirring rod until the sample was mixed well in the solution. The dispersed mixture was transferred into a $100 \mathrm{~mL}$ volumetric flask and diluted to the mark with distilled water. In a $50 \mathrm{~mL}$ volumetric flask, $10 \mathrm{~mL}$ of the diluted test solution was pipetted added with $5 \mathrm{~mL}$ of $0.1 \mathrm{~N} \mathrm{HCl}$, followed by $0.5 \mathrm{~mL}$ of iodine reagent. The volume was diluted to $50 \mathrm{~mL}$ and the absorbance was measured at $625 \mathrm{~nm}$ after $5 \mathrm{~min}$. A series of standard pure potato amylose type III (Sigma-Aldrich) (0\%, 10\%, 20\%, 40\%, 50\%, $60 \%, 80 \%, 90 \%$, and $100 \%$ ) was prepared using the same method as above. The regression equation from the standard curve was used to calculate the amylose content of the sample. 


\subsubsection{Vitamin C}

Vitamin C content was determined using the 2,6-dichlorophenol indophenol titration method [21]. The $2 \mathrm{~g}$ of samples for sweet potato tuber and flour samples (C1, C2, and C3) were filled into 50-mL Erlenmeyer flasks and homogenized with $5 \mathrm{~mL}$ of metaphosphoric acid-acetic acid solution. The samples were filtered and titrated with indophenol dye solution until a light rose-pink color persisted for $>5 \mathrm{~s}$. The initial and final readings were recorded and used to determine the amount of dye used for each titration. The volumes of dye used to titrate the samples were compared with titration for ascorbic acid standard in known concentration. Vitamin $C$ in the samples was calculated as below and expressed in $\mathrm{mg}$ ascorbic acid/mL:

$$
\mathrm{mg} \text { ascorbic acid } / \mathrm{mL}=(X-B) \times(F / E) \times(V / Y)
$$

where: $X=$ average $\mathrm{mL}$ for sample titration; $B=$ average $\mathrm{mL}$ for sample blank titration; $F=$ titer of dye ( $=\mathrm{mg}$ ascorbic acid equivalent to $1.0 \mathrm{~mL}$ indophenol standard solution); $E=\mathrm{ml}$ assayed $(=2 \mathrm{~mL}) ; V=$ volume of initial assay solution $(=7 \mathrm{~mL}) ; Y=$ volume of sample aliquot titrated $(=7 \mathrm{~mL})$.

\subsubsection{Statistical Analysis}

Data were analyzed as mean values and standard deviation (SD) using one-way analysis of variance (ANOVA) of IBM Statistic 22.0. The factor of processing conditions was analyzed at three different levels; $\mathrm{C} 1=$ Unpeeled sweet potato, $\mathrm{C} 2=$ Peeled sweet potato, and C3 $=$ Skin of sweet potato. Significant differences were established at $p \leq 0.05$ determined according to Tukey HSD (Honestly Significant Difference). The correlation coefficient was performed using Statistical Package for Social Sciences (SPSS Inc. Waker Drive, Chicago, IL, USA).

\section{Results}

\subsection{Dry Matter (DM)}

Table A1 shows the experimental data of dry matter content of sweet potato tuber and flour samples at three different conditions (C1, C2, C3). For the tuber sample, DM values of $\mathrm{C} 1, \mathrm{C} 2$, and C3 were $32.67,21.67$, and $8.67 \%$, respectively. The highest DM was found in C1 and it was parallel to the reported data by [22], where they found DM of unpeeled tuber ranged from 21.80 to $36.53 \%$. After the skin was peeled, sweet potato showed a significant reduction of DM content by $33.67 \%$ in C2. C3 contained $0.81 \%$ of DM from the unpeeled tuber (C1). C2 had higher DM than C3 by 60\%. This result agreed with an earlier report that the flesh of potato $(172.2 \mathrm{~g} / \mathrm{kg}$ fresh matter) had higher DM than the skin of potato $(159.6 \mathrm{~g} / \mathrm{kg}$ fresh matter) [23].

Similarly, the DM of sweet potato flour varied significantly to different conditions. C3 had the lowest DM, whereas C1 had the highest DM. This might due to the condition of C1 that included skin and flesh as compared to C2 and C3. Peeling caused a significant reduction of DM in C2, which was about $25 \%$. The differences in the average DM values of tuber and flour samples of three conditions confirmed that the solid content after removal of water varied according to the conditions. The values of DM observed in the different conditions corresponded to the organic and inorganic matter, which was important as it might affect the nutritional intake of consumers. Therefore, to avoid the reduction of DM, $\mathrm{C} 1$ was selected as the best condition for both sweet potato tuber and flour.

DM content is the most important attribute to determine the quality and yields of fried and dehydrated products. The high DM content or total solid is suitable for producing processed products with high recovery, low oil absorption, less energy consumption, and crispy texture [24]. 


\subsection{Ash Content}

The experimental data of ash content are presented in Table A1. The ash content of sweet potato tuber samples in the different conditions were varied significantly at $\mathrm{C} 1=4.13 \%, \mathrm{C} 2=2.10 \%$, and $\mathrm{C} 3=6.44 \%$. The results showed that $\mathrm{C} 3$ had the highest ash content, followed by $\mathrm{C} 1$ and $\mathrm{C} 2$. Meanwhile, the $\mathrm{C} 1$ value was significantly higher compared to C2. The reduction of ash content after skin removal was about $49.33 \%$ and it almost half of the loss. [25] reported that ash content reduced significantly after peeling in raw Brinjal, Bitter gourd, and Colocasia by $18.96 \%, 11.11 \%$, and $13.21 \%$, respectively.

For sweet potato flour, the ash content was obtained as followed; $\mathrm{C} 1=4.81 \%, \mathrm{C} 2=3.81 \%$ and C3 $=11.66 \%$. Similarly, the highest ash content was found in C3. As compared to the previous study by [26], they found lower ash content in the powder of pineapple peels $(4.39 \%)$, mango peels $(3.24 \%)$, and apple peels $(1.39 \%)$ but high in banana peels $(12.45 \%)$. However, there was no significant difference $(p>0.05)$ observed between $\mathrm{C} 1$ and $\mathrm{C} 2$ and it was in line with the finding by [27], in which the study found insignificant changes between unpeeled and peeled orange-sweet potato flour. Therefore, it can be suggested that peeling does not affect the ash content in the sweet potato flour.

Based on the above explanations, the ash content was found high in the outermost part of sweet potato, which was the skin for both tuber and flour samples. This significant data might due to the higher nutritious value commonly found in the outermost parts of the tuber through the inward part of the flesh [28]. Furthermore, the higher ash content is also related to the presence of heavy amounts of inorganic nutrients such as potassium, sodium, calcium, phosphorus, and magnesium in the peel of sweet potato [29-31]. Rationally, unpeeled tuber (C1) should have more ash content than the skin (C3), but this finding was reported oppositely. It might be due to the lower proportion of sweet potato skin than flesh during the preparation of the unpeeled sample, which contributed to the lower ash content.

\subsection{Moisture Content}

Table A1 shows the experimental data of the moisture content (MC) of sweet potato tuber and flour subjected to three different conditions. The mean MC of sweet potato tuber was found as the significantly highest in C3 with a value of $89.00 \%$ followed by C2 with $79.00 \%$, and C1 with $75.33 \%$. This finding was in parallel with a previous study by [32], which found that the skin $(70.80 \%)$ of cassava had significantly higher MC than the flesh $(62.25 \%)$. The differences in the average MC values of the three conditions showed that the water content varied according to the type of conditions. The higher moisture content of the sweet potato skin (C3) was expected due to the lower dry matter content.

Meanwhile, MC values for C1, C2, and C3 in sweet potato flour were $3.85 \%, 3.98 \%$, and $6.04 \%$, respectively. Similarly, the significantly highest MC was found in C3 followed by $\mathrm{C} 1$ and $\mathrm{C} 2$. However, an insignificant result $(p>0.05)$ was obtained between the mean $\mathrm{MC}$ of $\mathrm{C} 1$ and $\mathrm{C} 2$. This means that the peeling has not much affected the MC of the sweet potato flour. Furthermore, the MC of these three conditions were below $10 \%$, which were considered as a safe MC level for preventing undesired changes caused by spoilage microorganisms [33]. Moreover, the MC results obtained also below $15.5 \%$, which were specified as the maximum MC for wheat flour [34]. The high MC in flour may result in caking, a phenomenon caused by the aggregation of particles into lumps [35]. This will affect the flour quality and its functionality [36].

In addition, the $\mathrm{MC}$ of the sweet potato tuber was significantly decreased after being processed into flour. A lower MC of the flour than the tuber was expected due to the drying process. Furthermore, lower MC is suitable for extended postharvest utilization of sweet potato tubers as low moisture content in food materials slows down the growth of microbial pathogenic and brings about a substantial volume reduction [37]. Overall, the moisture content is a significant parameter to determine the water content in the food, as it can be used as an indicator of the stability and safety of the final product against microbial and enzymatic activities, which determines the shelf life [35]. 


\subsection{Crude Protein (CP)}

According to Table A1, the average $\mathrm{CP}$ of sweet potato tuber for $\mathrm{C} 1, \mathrm{C} 2$, and $\mathrm{C} 3$ of were $0.57 \%, 0.59 \%$, and $1.38 \%$, respectively. $\mathrm{CP}$ was found to be significantly higher in $\mathrm{C} 3$ than in $\mathrm{C} 1$ and $\mathrm{C} 2$. This finding was opposite to the study by [32], which reported an insignificant difference in protein content between flesh and skin of cassava. In addition, sweet potato skin (C3) was found to have lower CP than the skin of tomatoes $(10.5 \%)$ [38]. However, C1 and C2 showed an insignificant difference $(p>0.05)$ in CP. Therefore, it can be suggested that peeling does not affect the reduction of $\mathrm{CP}$ in sweet potato tuber.

In the case of sweet potato flour, the $\mathrm{CP}$ for $\mathrm{C} 1, \mathrm{C} 2$, and $\mathrm{C} 3$ were $7.78 \%, 7.84 \%$, and $8.66 \%$, respectively. From this data, C3 also showed the highest value of protein content among all conditions. Similar to tuber samples, there were no significant differences $(p>0.05)$ between $\mathrm{C} 1$ and $\mathrm{C} 2$ of flour samples. In this study, CP of unpeeled and peeled sweet potato flour ranged from 7.78 to $7.84 \%$. These values were in the range reported by [27], in which CP of unpeeled and peeled varied from 6.13 to $12.78 \%$. [7] also stated that the protein content in sweet potato flour was generally low, ranged from 1.0 to $8.5 \%$.

The present study raises the possibility that the protein content is found higher in the outermost part of sweet potato, which is its skin (C3). This result is in keeping with a previous study [23], which reported that potato peels showed significantly higher protein contents compared to the flesh. The presence of nitrogen content in amino acids contributes to the higher protein content [23]. Since the peel is directly contacted with soil, therefore it receives more nitrogen compared to the flesh. [37] also reported that sweet potato tuber $(1.82 \%)$ and flour $(1.70 \%)$ were not considered as rich protein sources. However, they contain a kind of protein known as sporamin that highly nutritional and biological potential [39]. In addition, the lower protein content during tubers generation might due to the increase in average mass and the accumulation of starch [40].

\subsection{Crude Fat}

From Table A1, the fat content of sweet potato tuber for $\mathrm{C} 1, \mathrm{C} 2$, and $\mathrm{C} 3$ were $0.51 \%$, $0.30 \%$, and $0.36 \%$, respectively. No significant difference $(p>0.05)$ in fat content was observed between each condition. However, the fat content in this study was found higher than other sweet potato cultivars of J6/66 (0.1\%) and Beauregard (0.2\%) [41]. The previous study by [40] also revealed low-fat content $(0.42 \%)$ of orange-fleshed sweet potato.

Meanwhile, the results obtained for the sweet potato flour of $\mathrm{C} 1, \mathrm{C} 2$, and $\mathrm{C} 3$ were accounted for 0.26 to $0.40 \%$ of fat content. Similarly, there was no significant difference $(p>0.05)$ detected between the conditions. The fat content in sweet potato skin (C3) found was lower than pineapple $(5.31 \%)$, mango $(4.72 \%)$, apple $(9.96 \%)$, and banana $(8.40 \%)$ [26]. The range of fat content in unpeeled (C1) and peeled (C2) was lower compared to the previous finding [27], which reported between 0.70 to $1.62 \%$. A lower fat content found in the sweet potato flour indicated that it is not susceptible to quick rancidity [42]. However, the reported fat content in this study was higher compared to cassava flour $(0.17$ to $0.20 \%$ ) [43].

The results of this study indicated that the low-fat content was found in sweet potato tuber and flour. Like other roots and tubers, sweet potato is known for its low-fat content [44]. Hence, it can easily be adjusted by a food processor for desired fat levels [4] and compensated by the ingredients in the food products which contain more fat [37]. Moreover, [39] stated that the fat content is important for sustaining texture, flavor and pigments of fruits. 


\subsection{Crude Fiber}

Table A2 compares the crude fiber results in sweet potato tuber and flour of different conditions ( $\mathrm{C} 1, \mathrm{C} 2$, and $\mathrm{C} 3)$. The crude fiber contained in $\mathrm{C} 1, \mathrm{C} 2$, and $\mathrm{C} 3$ of sweet potato tuber were $2.97 \%, 1.08 \%$, and $1.08 \%$, respectively. $\mathrm{C} 1$ resulted in the highest value of crude fiber, but no significant difference $(p>0.05)$ between C2 and C3. Hence, it is apparent from the data that the reduction values of $\mathrm{C} 2$ from $\mathrm{C} 1$ due to peeling caused a $63.63 \%$ loss of crude fiber. A similar finding was reported by a prior study, in which peeling caused the $32.58 \%$ loss of crude fiber in the tuber of Colocasia [25].

On the other hand, the mean of a crude fiber measured in flour for $\mathrm{C} 1, \mathrm{C} 2$, and C3 were $9.90 \%, 5.30 \%$, and $1.93 \%$, respectively. $\mathrm{C} 1$ showed the significantly highest crude fiber followed by C2 and C3. The loss of crude fiber affected by the peeling was about $46.89 \%$. The result of $C 1$ showed a higher value than $[45,46]$, which reported the crude fiber ranged from 2.1 to $8.5 \%$ for unpeeled sweet potato cultivars of Wariyapola red, Wariyapola white, Pallepola variety, and Malaysian variety. However, the crude fiber measured in C2 and C3 were lower than the values reported in the previous studies for potato flesh $(23.4 \mathrm{~g} / \mathrm{kg} \mathrm{DM})$ and skin $(65.1 \mathrm{~g} / \mathrm{kg} \mathrm{DM})$ flours [23].

Overall, C1 for both sweet potato tuber and flour contained the highest crude fiber. This study suggests that $\mathrm{C} 1$ is the best condition to maintain the high fiber content of sweet potato for good health by reducing the rate of glucose breakdown and absorption, therefore avoiding excess glucose in the human body and facilitating the breakdown of carbohydrate to glucose [47].

\subsection{Carbohydrate}

The carbohydrate content of sweet potato tuber and flour of different conditions ( $\mathrm{C} 1$, C2, C3) were illustrated in Table A2. The significantly highest carbohydrate content of sweet potato tuber was found in C1 $(46.32 \mathrm{mg} / \mathrm{mL})$ followed by C2 $(41.58 \mathrm{mg} / \mathrm{mL})$ and C3 $(25.38 \mathrm{mg} / \mathrm{mL})$. A significant reduction in C2 $(10.24 \%)$ was found when compared to C1. The finding by [48] found a lower content of carbohydrates in Nigerian potato tuber $(3.50 \mathrm{mg} / 100 \mathrm{~mL})$ and sweet potato tuber $(3.70 \mathrm{mg} / 100 \mathrm{~mL})$ in comparison to the present study. Several studies revealed carbohydrate content in fresh orange-fleshed sweet potatoes were between 21 to $28 \%$ [48,49].

Concerning flour samples, the values of the carbohydrate content in C1, C2, and C3 were reported as $173.54,134.44$, and $95.59 \mathrm{mg} / \mathrm{mL}$, respectively. In Table A2, C1 contained the significantly highest carbohydrate in comparison to C2 and C3. In contrast, the study by $[27,49]$ found that peeled orange-fleshed sweet potato flour had slightly lower total carbohydrates than unpeeled flour. Besides, the study by [18] found the lower carbohydrate in the flour of maize (Zea mays L.), which ranged from 63.03 to $69.36 \%$. Furthermore, the carbohydrate content in C2 was reduced by $22.53 \%$ from $\mathrm{C} 1$. Therefore, peeling caused a huge reduction of carbohydrates in sweet potato flour.

Moreover, these findings suggest that $\mathrm{C} 1$ is the best condition in providing higher carbohydrates than $\mathrm{C} 2$ and $\mathrm{C} 3$ for both sweet potato tuber and flour. It can be suggested that the consumption of sweet potato with the $\mathrm{C} 1$ condition will increase the intake of carbohydrates.

\subsection{Starch Content}

The results of the starch content analysis of $\mathrm{C} 1, \mathrm{C} 2$, and $\mathrm{C} 3$ conditions for both sweet potato tuber and flour are shown in Table A2. For tuber samples, the values of C1, C2, and C3 were ranged from 7.89 to $31.55 \%$. The data obtained showed that there was no significant difference $(p>0.05)$ between $\mathrm{C} 1$ and $\mathrm{C} 2$. Therefore, peeling does not affect the starch content in sweet potato tuber. However, the starch content of $\mathrm{C} 1$ and $\mathrm{C} 2$ were found significantly higher compared to $\mathrm{C} 3$. This was probably caused by the higher proportion of two major polymers; amylose and amylopectin, which were highly found in the flesh of sweet potato [50,51]. 
For flour samples, the starch content of C1 was $39.73 \%$, C2 was $42.53 \%$ and C3 was $20.11 \%$, which followed the same trend as the tuber samples. The highest content of starch was found in C1 and C2 while C3 recorded the lowest value. The starch content of C2 in this study was lower than the starch content of peeled sweet potato flour (56 to $84 \%$ ) reported by [19]. It might be due to the different cultivars and environmental variations.

In brief, the results described that the starch content in different conditions was significantly higher in sweet potato flour compared to the tuber. One possible explanation for this difference is the increase of amylose content during the heat treatment [51] in the making process of sweet potato flour proposed the increase of starch content in flour. In addition, $\mathrm{C} 1$ and $\mathrm{C} 2$ for both tuber and flour samples reflected the better value of starch content. Interestingly, these data showed that the peeling does not affect the starch content in sweet potato tuber and flour. Starch is the predominant fraction of the dry matter in sweet potato tubers [52]. It is a rich source of carbohydrates and provides energy to the diet. It acts as a dominant factor that determines the physical and chemical, rheological, and textural properties of starch-based food products. In the food industry, it is used as an important source of raw material for products such as noodles and glucose syrup [19], hence $\mathrm{C} 1$ and $\mathrm{C} 2$ flour with high starch content could be useful in these aspects.

\subsection{Amylose Content}

Table A2 presents the effects of conditions $(\mathrm{C} 1, \mathrm{C} 2, \mathrm{C} 3)$ on the amylose content of sweet potato tuber and flour. For tuber samples, amylose content was found to be significantly higher in C1 (9.97\%), followed by C2 (6.68\%) and C3 (3.94\%). However, all of them were classified as low amylose content, which below 10\%. C2 experienced almost 32.95\% loss of amylose content due to the peeling effect. This happened due to the presence of more polymer chains of glucose units connected by $\alpha$-acetal linkage [53]. The amylose content of C2 was found lower than the peeled sweet potato from Thailand varieties (16.5 to $18.5 \%$ ) [54], which might be due to different cultivars and processing methods.

The amylose content in sweet potato flour showed a significant difference among different conditions $(\mathrm{C} 1, \mathrm{C} 2, \mathrm{C} 3)$. $\mathrm{C} 1$ showed a significantly higher amylose content value of $17.22 \%$ than $\mathrm{C} 2$ and $\mathrm{C} 3$, which were $11.74 \%$ and $6.91 \%$, respectively. The percentage reduction of amylose content in $\mathrm{C} 2$ compared to $\mathrm{C} 1$ was $31.82 \%$. Hence, this reflects that the peeling does affect the amylose content of the sweet potato. $\mathrm{C} 1, \mathrm{C} 2$, and $\mathrm{C} 3 \mathrm{had}$ amylose content lower than $20 \%$. C1 and C2 can be classified as medium-amylose (10 to 30\%) while C3 is notable as low-amylose content $(<10 \%)$ [55]. The result of amylose content in C1 and C2 were consistent with the finding by [56], in which the amylose content of sweet potato varied between 0 to $34.16 \%$. Besides, the amylose content of $\mathrm{C} 1$ was higher compared to finding by [57], in which the amylose content in potato flour was reported between 10 to $25 \%$.

Overall, these results indicated that both sweet potato tuber and flour in $\mathrm{C} 1, \mathrm{C} 2$, and C3 contained low and medium-amylose content. Generally, amylose is a minor component of native starches; its structure and amount play important roles in determining the physical and chemical, and technological properties of starch [53]. Therefore, C1 was considered as the best condition to retain high amylose content for the processing purpose compared to other conditions.

\subsection{Vitamin $C$}

As shown in Table A2, the observed mean vitamin $C$ of the sweet potato tuber in $C 1$, C2, and C3 were ranged from 0.45 to $1.17 \mathrm{mg} / 100 \mathrm{~mL}$. No significant differences $(p>0.05)$ were found between each condition. The results in this current study hold the lower values of vitamin $C$ than the previous research by [8], where they reported $2.4 \mathrm{mg} / 100 \mathrm{~g}$ of vitamin $\mathrm{C}$ in sweet potato tuber. A prior study by [58] also reported higher vitamin $\mathrm{C}$ of sweet potato tuber range between 20.26 to $24.20 \%$. 
Turning now to the experimental data on sweet potato flour, the values of $\mathrm{C} 1, \mathrm{C} 2$, and C3 were 5.38, 11.47, and $7.84 \mathrm{mg} / 100 \mathrm{~mL}$, respectively. These data showed a similar trend with sweet potato tuber, which no significant differences $(p>0.05)$ detected among each condition. However, the values of vitamin $C$ in these three conditions were higher than the VitAto powder $(1.33 \mathrm{mg} / 100 \mathrm{~g})$ as reported by [42]. A higher value of vitamin C reported by [8], ranged between 17.3 to $34.5 \mathrm{mg} / 100 \mathrm{~g}$ for the sweet potato roots.

Interestingly, the vitamin $C$ content was not influenced by the conditions $(C 1, C 2$, C3) of sweet potato. This retention of vitamin $C$ was might be influenced by the slice thickness of the sweet potato during the sample preparation [59]. The slice thickness effect could be attributed to the higher holding capacity of vitamin $C$. It is important to note that vitamin $C$ is an essential vitamin for the proper functioning of the human body to prevent hemorrhagic disease scurvy, maintain redox balance, synthesize amino acids, develop connective tissues, and absorb iron in the gastrointestinal tract $[57,58]$.

\section{Conclusions}

In this study, the effect of peeling on the physical and chemical properties of the most important sweet potato cultivar (cv. Anggun 1) harvested in the western region of Malaysia was determined. It is clear that the unpeeled sweet potato tuber and flour (C1) is more significant in improving the quality of sweet potato and has very strong potential for practical application in the food industry. Furthermore, it has been proven to reduce the loss of physical and chemical properties and enhance the stability of sweet potato with better nutritional value as well as many beneficial attributes that urge its industrial application. Therefore, it was suggested that the unpeeled sweet potato flour could be used to make a higher quality end product that is more attractive for product developers and consumers.

Author Contributions: Conceptualization, N.S., R.S., M.Z.M.N. and N.H.; formal analysis, N.S.; funding acquisition, R.S.; investigation, N.S.; supervision, R.S., M.Z.M.N. and N.H. All authors have read and agreed to the published version of the manuscript.

Funding: This research was funded by Universiti Putra Malaysia, grant number GP-IPB/2018/9660301.

Institutional Review Board Statement: Not applicable.

Informed Consent Statement: Informed consent was obtained from all subjects involved in the study.

Data Availability Statement: All data are provided within this paper.

Acknowledgments: The authors express their gratitude to the Universiti Putra Malaysia for providing financial and technical support under grant GP-IPB/2018/9660301 to conduct this research work.

Conflicts of Interest: The authors declare no conflict of interest. 


\section{Appendix A}

Table A1. Physicochemical properties of different conditions of Anggun 1 (C1, C2, and C3).

\begin{tabular}{|c|c|c|c|c|c|c|c|c|c|c|}
\hline \multirow{2}{*}{ Sample } & \multicolumn{2}{|c|}{ Dry Matter (\%) } & \multicolumn{2}{|c|}{ Ash (\%) } & \multicolumn{2}{|c|}{ Moisture (Wet Basis) (\%) } & \multicolumn{2}{|c|}{ Crude Protein (\%) } & \multicolumn{2}{|c|}{ Crude Fat (\%) } \\
\hline & Raw & Flour & Raw & Flour & Raw & Flour & Raw & Flour & Raw & Flour \\
\hline C1 & $32.67 \pm 0.57^{\mathrm{a}}$ & $36.00 \pm 1.00^{\mathrm{a}}$ & $4.13 \pm 0.74^{\mathrm{c}}$ & $4.81 \pm 0.11^{b}$ & $75.33 \pm 0.58^{c}$ & $3.85 \pm 0.07^{b}$ & $0.57 \pm 0.03^{b}$ & $7.78 \pm 0.03^{b}$ & $0.51 \pm 0.08^{a}$ & $0.40 \pm 0.13^{\mathrm{a}}$ \\
\hline $\mathrm{C} 2$ & $21.67 \pm 0.58^{b}$ & $27.00 \pm 2.00^{b}$ & $2.10 \pm 0.08^{b}$ & $3.81 \pm 0.47^{b}$ & $79.00 \pm 1.00^{b}$ & $3.98 \pm 0.06^{b}$ & $0.59 \pm 0.11^{b}$ & $7.84 \pm 0.05^{b}$ & $0.30 \pm 0.20^{\mathrm{a}}$ & $0.26 \pm 0.09^{\mathrm{a}}$ \\
\hline $\mathrm{C} 3$ & $8.67 \pm 1.53^{c}$ & $11.00 \pm 1.00^{\mathrm{c}}$ & $6.44 \pm 1.18^{\mathrm{a}}$ & $11.66 \pm 1.32^{\mathrm{a}}$ & $89.00 \pm 1.00^{\mathrm{a}}$ & $6.04 \pm 0.09^{\mathrm{a}}$ & $1.38 \pm 0.09^{a}$ & $8.66 \pm 0.37^{\mathrm{a}}$ & $0.36 \pm 0.08^{a}$ & $0.37 \pm 0.07^{\mathrm{a}}$ \\
\hline
\end{tabular}

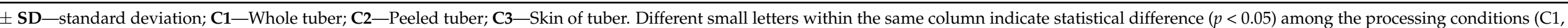

$\mathrm{C} 2, \mathrm{C} 3)$ on Tukey's HSD comparison test for three replications.

Table A2. Physicochemical properties of different conditions of Anggun 1 (C1, C2, and C3)—continued.

\begin{tabular}{|c|c|c|c|c|c|c|c|c|c|c|}
\hline \multirow{2}{*}{ Sample } & \multicolumn{2}{|c|}{ Crude Fiber (\%) } & \multicolumn{2}{|c|}{$\begin{array}{c}\text { Carbohydrate } \\
\text { (mg Glucose } / \mathrm{mL} \text { ) }\end{array}$} & \multicolumn{2}{|c|}{ Starch $(\%)$} & \multicolumn{2}{|c|}{ Amylose (g/100 g) } & \multicolumn{2}{|c|}{ Vitamin C (mg/100 mL) } \\
\hline & Raw & Flour & Raw & Flour & Raw & Flour & Raw & Flour & Raw & Flour \\
\hline $\mathrm{C} 1$ & $2.97 \pm 0.64^{\mathrm{a}}$ & $9.90 \pm 1.22^{a}$ & $46.32 \pm 1.56^{\mathrm{a}}$ & $173.54 \pm 9.43^{\mathrm{a}}$ & $20.84 \pm 0.19^{a}$ & $39.73 \pm 2.24^{a}$ & $9.97 \pm 0.80^{\mathrm{a}}$ & $17.22 \pm 1.02^{\mathrm{a}}$ & $0.45 \pm 0.25^{\mathrm{a}}$ & $5.38 \pm 0.91^{a}$ \\
\hline $\mathrm{C} 2$ & $1.08 \pm 0.02^{b}$ & $5.30 \pm 0.73^{b}$ & $41.58 \pm 0.64^{b}$ & $134.44 \pm 7.79^{b}$ & $20.48 \pm 0.28^{a}$ & $42.53 \pm 0.77^{\mathrm{a}}$ & $6.68 \pm 0.31^{b}$ & $11.74 \pm 0.54^{b}$ & $1.17 \pm 0.43^{\mathrm{a}}$ & $11.47 \pm 2.15^{\mathrm{a}}$ \\
\hline $\mathrm{C} 3$ & $1.08 \pm 0.09^{b}$ & $1.93 \pm 0.93^{c}$ & $25.38 \pm 2.64^{c}$ & $95.59 \pm 9.39^{c}$ & $15.50 \pm 0.35^{b}$ & $20.11 \pm 1.36^{b}$ & $3.94 \pm 0.22^{c}$ & $6.91 \pm 0.44^{\mathrm{c}}$ & $0.74 \pm 0.75^{\mathrm{a}}$ & $7.84 \pm 3.92^{a}$ \\
\hline
\end{tabular}

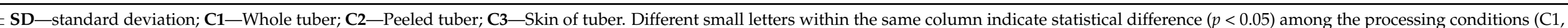
$\mathrm{C} 2, \mathrm{C} 3)$ on Tukey's HSD comparison test for three replications. 


\section{References}

1. Yusoff, M.M.; Abdullah, S.N.; Ridzwan, M.; Halim, A. Growth and Yield Performance of Five Purple Sweet Potato (Ipomoea batatas). Access. Colluvium Soil 2018, 41, 975-986.

2. Shafienaz, N.A.; Najib, M.; Omar, H.; Jupri, A. Tuber Yields of Three MARDI Purple Flesh Sweet Potatoes Varieties as Affected by Different Age of Planting Material. Malays. Soc. Plant Physiol. 2019, 2016, 289-291.

3. Oke, M.O.; Workneh, T.S. A review on sweet potato postharvest processing and preservation technology. Afr. J. Agric. Res. 2013, $1,1-14$.

4. Bovell-Benjamin, A.C. Sweet Potato: A Review of its Past, Present, and Future Role in Human Nutrition. Adv. Food Nutr. Res. 2007, 52, 1-59. [CrossRef]

5. Ganhao, R.; Pinheiro, J.; Tino, C.; Faria, H.; Gil, M.M. Characterization of Nutritional, Physicochemical, and Phytochemical Composition and Antioxidant Capacity of Three Strawberry 'Fragaria _ ananassa Duch.' Cultivars ('Primoris', 'Endurance', and 'Portola') from Western Region of Portugal. Foods 2019, 8, 682. [CrossRef] [PubMed]

6. Wang, S.; Nie, S.; Zhu, F. Chemical constituents and health effects of sweet potato. Food Res. Int. 2016, 89, 90-116. [CrossRef] [PubMed]

7. Van Hal, M. Quality of Sweetpotato Flour During Processing and Storage. Food Rev. Int. 2000, 16, 1-37. [CrossRef]

8. Truong, V.D.; Avula, R.Y.; Pecota, K.V.; Yencho, G.C. Sweetpotato Production, Processing, and Nutritional Quality. Handb. Veg. Veg. Process. 2018, 2, 811-838. [CrossRef]

9. Ahmed, M.; Akter, M.S.; Eun, J.-B. Peeling, drying temperatures, and sulphite-treatment affect physicochemical properties and nutritional quality of sweet potato flour. Food Chem. 2010, 121, 112-118. [CrossRef]

10. Kaur, M.; Sandhu, K.S. Sweet Potato Flour and Starch. Trop. Roots Tubers 2016, 479-506. [CrossRef]

11. Mousia, Z.S.; Edherly, S.; Pandiella, S.S.; Webb, C. Effect of wheat pearling on flour quality. Food Res. Int. 2004, 37, 449-459. [CrossRef]

12. Singh, S.; Singh, N. Effect of debranning on the physico-chemical, cooking, pasting and textural properties of common and durum wheat varieties. Food Res. Int. 2010, 43, 2277-2283. [CrossRef]

13. Shaari, N.; Shamsudin, R.; Nor, M.M.; Hashim, N. Phenolic, flavonoid and anthocyanin contents of local sweet potato (Ipomoea batatas). Food Res. 2020, 4, 74-77. [CrossRef]

14. Onwude, D.; Hashim, N.; Abdan, K.; Janius, R.; Chen, G. Investigating the influence of novel drying methods on sweet potato (Ipomoea batatas L.): Kinetics, energy consumption, color, and microstructure. J. Food Process. Eng. 2018, 41, e12686. [CrossRef]

15. Nair, A.G.H.; Prasannakumari, V.; Vijayan, A. Evaluation of orange fleshed sweet potato genotypes for storage root yield and dry matter content. Int. J. Appl. Pure Sci. Agric. 2017, 3, 82-85.

16. AOAC. Official methods of analysis of the Association of Official Analytical Chemists (method 945.46). In Official Methods of Analysis of the Association of Official Analytical Chemists; Association of Official Analytical Chemists: Arlington, VI, USA, 1997.

17. AOAC, Association of Official Analytical. Official methods of analysis of AOAC international; AOAC: Arlington, VI, USA, 1990.

18. Khan, A.H.; Minhas, N.M.; Asasd, M.J.; Iqbal, A.; Ilyas, M.; Mahmood, R.T. Estimation of Carbohydrate, Starch, Protein and Oil Contents of Maize (Zea mays). Eur. J. Acad. Res. 2014, 2, 5230-5240.

19. Olatunde, G.O.; Henshaw, F.O.; Idowu, M.A.; Tomlins, K. Quality attributes of sweet potato flour as influenced by variety, pretreatment and drying method. Food Sci. Nutr. 2015, 4, 623-635. [CrossRef] [PubMed]

20. Hoover, R.; Ratnayake, W.S. Determination of Total Amylose Content UNIT E2.3 of Starch. Handb. Food Anal. Chem. 2001, 2, 679-687.

21. Nielsen, S.S. Vitamin C Determination by Indophenol Method. In Food Science Text Series; J.B. Metzler: Stuttgart, Germany, 2017; pp. 143-146.

22. Wang, X.; Tian, S.; Lou, H.; Zhao, R. A reliable method for predicting bioethanol yield of different varieties of sweet potato by dry matter content. Grain Oil Sci. Technol. 2020, 3, 110-116. [CrossRef]

23. Vaitkevičienè, N. A comparative study on proximate and mineral composition of coloured potato peel and flesh. J. Sci. Food Agric. 2019, 99, 6227-6233. [CrossRef] [PubMed]

24. Marwaha, R.S.; Pandey, S.K.; Singh, S.V.; Khurana, S.M.P. Processing and nutritional qualities of Indian and exotic potato cultivars as influenced by harvest date, tuber curing, pre-storage holding period, storage and reconditioning under short days. Adv. Hortic. Sci. 2005, 47, 137-156.

25. Alvi, S.; Khan, K.M.; Sheikh, M.A.; Shahid, M. Effect of Peeling and Cooking on Nutrients in Vegetables, Pakistan. J. Nutr. 2003, 2, 189-191.

26. Dibanda, F.; Romelle, R.P.; Manohar, R.S. Chemical composition of some selected fruit peels. Eur. J. Food Sci. Technol. 2016, 4, 12-21.

27. Chikpah, S.K.; Korese, J.K.; Hensel, O.; Sturm, B. Effect of Sieve Particle Size and Blend Proportion on the Quality Properties of Peeled and Unpeeled Orange Fleshed Sweet Potato Composite Flours. Foods 2020, 9, 740. [CrossRef]

28. Abdullah, N.; Zulkifli, K.S.; Abdullah, A.; Aziman, N.; Kamarudin, W.S.S.W. Assessment on the antioxidant and antibacterial activities of selected fruit peels. Int. J. ChemTech Res. 2012, 4, 1534-1542. Available online: http://www.sphinxsai.com/2012/oct$\mathrm{dec} /$ chempdf $/ \mathrm{CT}=42(1534-1542)$ OD12.pdf (accessed on 20 February 2021).

29. Czech, A.; Zarycka, E.; Yanovych, D.; Zasadna, Z.; Grzegorczyk, I.; Kłys, S. Mineral Content of the Pulp and Peel of Various Citrus Fruit Cultivars. Biol. Trace Element Res. 2019, 193, 555-563. [CrossRef] [PubMed] 
30. Aletor, O.; Oshodi, A.; Ipinmoroti, K. Chemical composition of common leafy vegetables and functional properties of their leaf protein concentrates. Food Chem. 2002, 78, 63-68. [CrossRef]

31. Iqbal, S.; Younas, U.; Sirajuddin; Chan, K. W.; Sarfraz, R.A.; Uddin, K.; Uddin, K. Proximate Composition and Antioxidant Potential of Leaves from Three Varieties of Mulberry (Morus sp.): A Comparative Study. Int. J. Mol. Sci. 2012, 13, $6651-6664$. [CrossRef] [PubMed]

32. Somendrika, M.A.D.; Wickramasinghe, I.; Wansapala, M.A.J.; Peiris, S. Proximate Composition of the Flesh and the Peel of Sri Lankan Cassava Variety ‘ MU-51. Int. J. Innov. Res. Technol. 2017, 4, 267-270.

33. Geankoplis, C.J. Transport Processes and Unit Operations; Prentice Hall: Englewood Cliffs, NJ, USA, 2003.

34. Stan, C. Codex Standard for Wheat Flour. Packaging; W.T.O.: Boston, MA, USA, 1995; pp. 1-3.

35. Tortoe, C.; Akonor, P.T.; Koch, K.; Menzel, C.; Adofo, K. Physicochemical and functional properties of flour from twelve varieties of Ghanaian sweet potatoes. Int. Food Res. J. 2017, 24, 2549-2556.

36. Aguilera, J.; del Valle, J.; Karel, M. Caking phenomena in amorphous food powders. Trends Food Sci. Technol. 1995, 6, 149-155. [CrossRef]

37. Curayag, Q.A.L.; Dizon, E.I.; Hurtada, W.A. Antioxidant activity, chemical and nutritional properties of raw and processed purple-fleshed sweet potato (Ipomoea batatas Lam.). Cogent Food Agric. 2019, 5, 1662930. [CrossRef]

38. Elbadrawy, E.; Sello, A. Evaluation of nutritional value and antioxidant activity of tomato peel extracts. Arab. J. Chem. 2016, 9, S1010-S1018. [CrossRef]

39. Rahman, N.F.; Shamsudin, R.; Ismail, A.; Abdul Karim Shah, N.N. Effects of Post-Drying Method on Pomelo Fruit Peels. Food Sci. Biotechnol. 2016, 25, 85-90. [CrossRef]

40. Nielsen, S.S. Food Analysis; Springer: New York, NY, USA, 2010.

41. Wang, C.H.S.; Mu, T.; Zhang, M. Sweet Potato Processing Technology; China Science Publishing \& Media: Beijing, China, 2017.

42. Rodrigues, N.; Barbosa, J.L.; Barbosa, M.I.M.J. Determination of physico-chemical composition, nutritional facts and technological quality of organic orange and purple-fleshed sweet potatoes and its flours. Int. Food Res. J. 2016, 23, 2071-2078.

43. Bovell-Benjamin, A.C.; Gichuhi, P.; Abdalla, M.; Biswas, M.; Bromfield, E.; Alvarez, M.; Kpomblekou, A.K.; Dean, D. Bulk Ingredients from Three Cultivars of Sweetpotatoes: Composition and Properties. In Vegetables Processing and Bioactive Compounds; SAE International: Warrendale, PA, USA, 2004.

44. Hanim, M.; Chin, N.L. Yusof, Y.A. Physico-chemical and flowability characteristics of a new variety of Malaysian sweet potato, VitAto Flour. Int. Food Res. J. 2014, 21, 2099-2107.

45. Chisté, R.; Cohen, K.; Mathias, E.; Ramoa, A. Estudo das propriedades físico-químicas e microbiológicas no processamento da farinha de mandioca do grupo d'água Study of physical-chemical and microbiological properties when processing cassava flour from the water group. Food Sci. Technol. 2007, 27. [CrossRef]

46. Aina, A.J.; Falade, K.O.; Akingbala, J.O.; Titus, P. Physicochemical properties of twenty-one Caribbean sweet potato cultivars. Int. J. Food Sci. Technol. 2009, 44, 1696-1704. [CrossRef]

47. Senanayake, S.A.; Ranaweera, K.K.D.S.; Gunaratne, A.; Bamunuarachchi, A. Comparative analysis of nutritional quality of five different cultivars of sweet potatoes (I pomea batatas (L) Lam) in SriLanka. Food Sci. Nutr. 2013, 1, 284-291. [CrossRef] [PubMed]

48. Brennan, C.S.; Samyue, E. Evaluation of Starch Degradation and Textural Characteristics of Dietary Fiber Enriched Biscuits. Int. J. Food Prop. 2004, 7, 647-657. [CrossRef]

49. Ikanone, C.; Oyekan, P. Effect of Boiling and Frying on the Total Carbohydrate, Vitamin C and Mineral Contents of Irish (Solanun tuberosum) and Sweet (Ipomea batatas) Potato Tubers. Niger. Food J. 2014, 32, 33-39. [CrossRef]

50. Alam, M.K.; Rana, Z.H.; Islam, S.N. Comparison of the Proximate Composition, Total Carotenoids and Total Polyphenol Content of Nine Orange-Fleshed Sweet Potato Varieties Grown in Bangladesh. Foods 2016, 5, 64. [CrossRef] [PubMed]

51. FAO. Improving of Nutrition through Home Gardening A Training Package for Preparing Filed Workers in Africa; FAO: Rome, Italy, 2001.

52. Mu, T.; Sun, H.; Zhang, M.; Wang, C. Sweet Potato Starch and its Series Products. In Sweet Potato Processing Technology; Elsevier BV: Amsterdam, The Netherlands, 2017; pp. 1-48.

53. Ravindran, V.; Ravindran, G.; Sivakanesan, R.; Rajaguru, S.B. Biochemical and Nutritional Assessment of Tubers from 16 Cultivars of Sweetpotato (Ipomoea batatas L.). J. Agric. Food Chem. 1995, 43, 2646-2651. [CrossRef]

54. Mu, T.-H.; Zhang, M. Sweet potato starch. Sweet Potato; Chem. Process. Nutr. 2019, 2019, 27-68. [CrossRef]

55. Soison, B.; Jangchud, K.; Jangchud, A.; Harnsilawat, T.; Piyachomkwan, K. Characterization of starch in relation to flesh colors of sweet potato varieties. Int. Food Res. J. 2015, 22, 2302-2308.

56. Tortoe, C.; Akonor, P.T.; Koch, K.; Menzel, C.; Adofo, K. Amylose and amylopectin molecular fractions and chain length distribution of amylopectin in 12 varieties of Ghanaian sweet potato (Ipomoea batatas) flours. Int. J. Food Prop. 2017, 20, 3225-3233. [CrossRef]

57. Zhu, F.; Wang, S. Physicochemical properties, molecular structure, and uses of sweetpotato starch. Trends Food Sci. Technol. 2014, 36, 68-78. [CrossRef]

58. Q. Lin, H.; Liu, P.; Xu, Z.; Zhang, F. Gong, and Z. Wang, Study on the physical and chemical properties of potato powder. Chem. Eng. Trans. 2017, 59, 781-786.

59. Krochmal-Marczak, B.; Sawicka, J.; Supski, T.; Cebulak, K.; Pigonia, S. Nutrition value of the sweet potato (Ipomoea batatas (L.) Lam) cultivated in south-eastern Polish conditions. Int. J. Agric. Res. 2014, 4, 169-178. 